\title{
A POWERHOUSE PARLIAMENT? AN ENDURING SETTLEMENT? THE SCOTLAND ACT 2016
}

\section{Aileen McHarg ${ }^{*}$}

The short articles in this special section explore the implications for the future governance of Scotland of key provisions in the Scotland Act 2016. Chris Himsworth discusses the "constitutional clauses" - section 1 declaring the permanence of the devolved institutions, and section 2 which puts the Sewel Convention on a statutory footing. Paul Reid examines the Scottish Parliament's newlyacquired powers over its own elections and composition, while David Cabrelli looks at its enhanced powers in relation to equalities. Sandra Eden and Tom Mullen consider the Act's most significant provisions in practical terms, namely those relating to taxation and welfare respectively. Aileen McHarg discusses devolution of the Crown Estate in Scotland, Gavin Little considers other new energy policy competences, and finally Mary Neal explores the future of abortion law in Scotland, which was a belated addition to the devolution package.

The enactment of the 2016 Act was the somewhat unexpected conclusion to the Scottish independence referendum held on 18 September 2014. Having been presented with a binary choice between independence or the constitutional status quo, voters ended up with an option which was not on the ballot paper (but which was present throughout the independence debate): a substantial revision to the devolution settlement involving considerable new powers for the Scottish Parliament and Scottish Ministers, and an enhanced constitutional status for devolution. ${ }^{1}$ These would, according to the UK Government, deliver a "powerhouse Parliament", ${ }^{2}$ and "an enduring constitutional settlement" for Scotland within the UK. ${ }^{3}$

Nevertheless, with the ink barely dry on the 2016 Act, and its provisions not yet fully in force, the question of Scotland's constitutional future is firmly back on the political agenda. This is thanks to the decision in the referendum of 23 June 2016 by a narrow, but clear majority of voters across the UK to leave the European Union, while $62 \%$ of voters in Scotland chose to remain. The EU referendum took place just as this special section was being finalised, and so its implications are not yet clear at the time of writing. However, the prospect of a second independence referendum, or a radically reformed constitutional settlement whereby Scotland (and Northern Ireland) can remain within the EU, whilst still remaining part of the UK, are both being widely discussed. The Scotland Act 2016 may therefore prove to be a short-lived staging post on the way to a much more autonomous constitutional future for Scotland.

However, even without the complication of Brexit, it is questionable whether the UK Government's claims about the 2016 Act stand up to scrutiny. The Act undoubtedly breaks new constitutional ground, both in terms of the legal guarantees it offers to the devolved institutions, and in the nature of the new powers being devolved - especially in relation to taxation, welfare, and the ability of the Scottish Parliament to control its own composition. But, as the articles in this special section demonstrate, the Act often seems to promise more than it actually delivers. The new

\footnotetext{
* Professor of Public Law, University of Strathclyde.

${ }^{1}$ For discussion of the genesis of the Scotland Act, see A Page, "The Smith Commission and Further Powers for the Scottish Parliament" (2015) 19 Edin LR 234.

2 See, eg, "Cameron: Holyrood Can Become a Powerhouse Parliament', BBC News, 2 October 2015, http://www.bbc.co.uk/news/uk-scotland-scotland-politics-34427226.

${ }^{3}$ HM Government, Scotland in the United Kingdom: an Enduring Settlement $(\mathrm{Cm} 8990,2015)$.
} 
powers are hedged about with legal and practical restrictions and qualifications, which will limit the potential for bold action by the devolved institutions. In some cases, the tensions within the new arrangements may threaten the stability of the devolution settlement itself.

The shortcomings of the 2016 Act are in large part due to the process by which it was arrived at. As is well known, the proposals derived from the report of the Smith Commission, ${ }^{4}$ which was set up immediately after the independence referendum result was announced to broker a deal between representatives of Scotland's five main political parties against an artificially imposed timetable dictated by the infamous "Vow" that appeared on the front page of the Daily Record on 16 September 2014. While the Commission succeeded in reaching agreement in record time (no pun intended), this was the expense of any meaningful public participation in the process or any attempt to articulate a coherent rationale for the package of measures proposed. The reforms were also entirely focused on Scotland. There has been no attempt to recast the broader UK constitutional framework to accommodate increased autonomy for Scotland, whilst enhancing the countervailing forces that hold the UK together. There was always a strong risk that such a rushed and piecemeal constitutional "settlement" would prove to be too fragile to weather a serious crisis. The architects of the Scotland Act $\mathbf{2 0 1 6}$ may well discover that to legislate in haste, is to repent at leisure.

\footnotetext{
${ }^{4}$ Report of the Smith Commission for Further Devolution of Powers to the Scottish Parliament (2014).
} 